finding that, on electrophoresis, $90 \%$ of the supernatant enzyme migrates to the anode, whereas the anode component of the mitochondrial enzyme represents only $14 \%$ of the total (Wieland, Pfleiderer, Haupt \& Worner, 1959). Evidence for two components with malic-dehydrogenase activity was obtained during chromatography of preparations from cauliflowers and peas (Figs. 1 and 2), but the separation did not appear to be connected with differences in specificity (Table 2).

It appears to the author that the existence of protein interactions and the likelihood of proteolytic activity modifying the structure of enzymes without destroying catalytic activity make it quite likely that electrophoresis or chromatography will indicate the presence of two peaks of activity in many enzyme preparations. The observation of multiple peaks may be unimportant unless a physiological difference between the molecular species of the enzyme is found. The existence of different enzymes catalysing the same reaction is potentially of great interest. The discovery of two examples in bacteria, the existence of two threonine deaminases, one of which is biosynthetic whereas the other is adaptive and degradative (Umbarger \& Brown, 1957), and the demonstration of two distinct systems for the synthesis of acetolactate, only one of which appears to participate in valine biosynthesis (Halpern \& Umbarger, 1959), suggest that the pattern of two enzymes catalysing the same reaction may be found in other biological systems.

\section{SUMMARY}

1. A method of purifying malic dehydrogenase from pea epicotyls is described. A 50-fold purification was obtained by ammonium sulphate fractionation, treatment with calcium phosphate gel and chromatography on diethylaminoethylcellulose.

2. Evidence is presented for the view that plant malic dehydrogenase, like the corresponding animal enzyme, is an $\alpha$-hydroxydicarboxylic acid dehydrogenase.

3. A number of kinetic constants have been evaluated.

4. Slight differences between malic dehydrogenase prepared from mitochondria and from the supernatant remaining after removing mitochondria from a homogenate were noted. Two peaks with malic-dehydrogenase activity were observed during chromatography but all preparations appeared to have the same substrate specificity.

I wish to thank Professor T. A. Bennet-Clark, F.R.S., for advice, Mr R.J. Ellis for carrying out the assays of glutamicoxaloacetic transaminase, Miss J. Bloom for technical assistance, and The Royal Society and the Agricultural Research Council for grants towards the cost of apparatus.

\section{REFERENCES}

Davies, D. D. \& Kun, E. (1957). Biochem. J. 66, 307.

Delbruck, A., Schimassek, H., Bartsch, K. \& Bücher, Th. (1959). Biochem. Z. 331, 297.

Halpern, Y. S. \& Umbarger, H. E. (1959). J. biol. Chem. 234, 3067.

Hess, B. (1958). Ann. N.Y. Acad. Sci. 75, 292.

Keilin, D.\& Hartree, E. F. (1938). Proc. Roy.Soc. B, 124, 397. Michaelis, L. \& Menten, M. L. (1913). Biochem. Z. 49, 333.

Millerd, A. \& Bonner, J. (1954). Arch. Biochem. Biophys. $49,343$.

Price, C.A.\& Thimann, K.V. (1954). Plant Physiol. 29, 495.

Stafford, H. A. (1956). Plant Physiol. 31, 135.

Stafford, H. A. (1957). Plant Physiol. 32, 338.

Thorn, M. B. (1949). Nature, Lond., 164, 27.

Umbarger, H. E. \& Brown, B. J. (1957). J. Bact. 73, 105.

Vessel, E. S. \& Bearn, A. G. (1958). Ann. N.Y. Acad. Sci. 75, 286.

Warburg, O. \& Christian, W. (1942). Biochem. Z. 310, 384.

Weiland, Th., Pfleiderer, G., Haupt, I. \& Worner, W. (1959). Biochem. Z. 332, 1.

Whittaker, V. P. \& Adams, D. H. (1949). Nature, Lond., 164, 315 .

Biochem. J. (1961) 80, 99

\title{
The Determination of Magnesium in Biological Materials by Atomic Absorption Spectrophotometry
}

\author{
By J. B. DAWSON* AND F. W. HEATON \\ Department of Medical Physics, University of Leeds, and Medical Research Council Unit \\ for Metabolic Disturbances in Surgery, The General Infirmary, Leeds, 1
}

\section{(Received 28 December 1960)}

The wide variety of methods which have been employed for the determination of magnesium in biological materials serves to illustrate the fact that no method is completely satisfactory. The

* Medical Research Council External Staff. majority of methods are chemical and the earlier procedures require an initial separation of magnesium, either as the insoluble ammonium phosphate salt (Briggs, 1922; Denis, 1922), or as the complex with 8-hydroxyquinoline (Greenberg \& Mackey, 1932). Direct combination with the dye 
Titan yellow has been widely used (Gillam, 1941; Garner, 1946; Orange \& Rhein, 1951), whereas more recently methods utilizing other dyestuffs and titration with ethylenediaminetetra-acetic acid have been developed (Smith, 1955; Wilkinson, 1957). Unfortunately many of these methods are inaccurate or of very limited application, owing to interference by other constituents of biological materials.

It is desirable that any method should be applicable to the analysis of ashed specimens of faeces and food or other cellular material in addition to biological fluids such as serum and urine. Modifications of existing ammonium phosphateseparation methods have been shown to yield satisfactory results with all types of specimen (Heaton, 1960), but as the analysis requires 2 days a more rapid method is necessary for many purposes.

During the past few years flame photometry has been applied to the problem (Vallee \& Margoshes, 1956; MacIntyre \& Davidsson, 1958), but the method is of low sensitivity, owing to the weak emission of the magnesium ion compared with the flame background, unless either very high flame

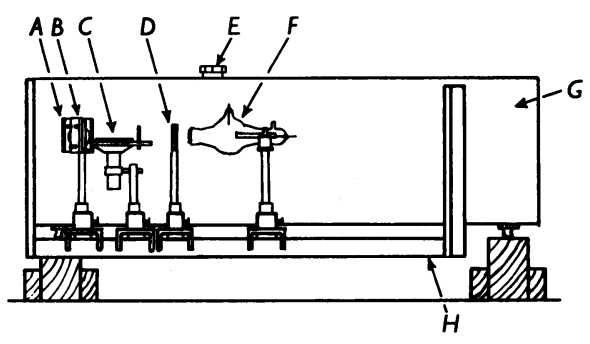

Rear elevation

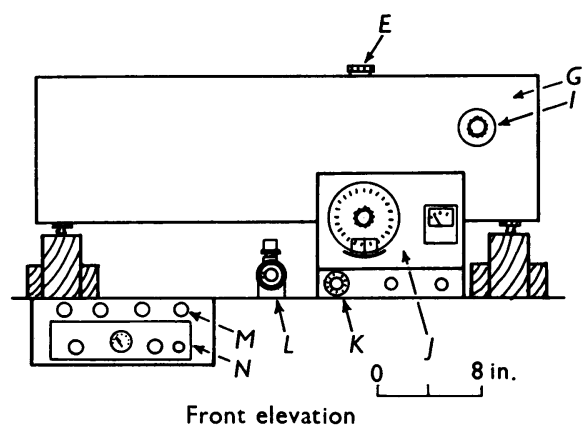

Fig. 1. Arrangement of atomic absorption spectrophotometer. $A$, Entrance slit of monochromator; $B$, mirror; $C$, burner; $D$, condenser lens; $E$, wavelength control; $F$, magnesium lamp; $G$, monochromator and detection system; $H$, optical bench; $I$, slit-width control; $J$, extinction scale and null-point meter; $K$, needle valve; $L$, atomizer and spray chamber; $M$, sensitivity controls; $N$, lamp-current controls. temperatures or integrating systems are employed (Exley \& Sproat, 1958). Greater sensitivity may be obtained by utilizing the principle of atomic absorption spectroscopy suggested by Walsh (1955). This principle has been used by Allan (1958) and David (1958) to determine several metals in biological materials after preliminary ashing, and by Willis $(1960 a, b)$ to estimate calcium and magnesium in serum after simple dilution.

The estimation of magnesium by atomic absorption spectroscopy involves passing light containing a high proportion of magnesium resonance radiation through a flame. Into the flame are aspirated solutions whose magnesium content is to be determined, and the light absorbed at $285.213 \mathrm{~m} \mu$ is compared with the absorption of a standard magnesium solution treated similarly. An instrument suitable for atomic absorption spectrophotometry has been constructed in this laboratory and the method examined for the analysis of both biological fluids and solutions of the ash obtained from cellular materials.

The classical magnesium ammonium phosphate separation method has been critically examined and its accuracy determined. By comparing the results of this method with those obtained from the same specimens analysed by atomic absorption spectrophotometry, the absolute accuracy of the latter method has been estimated.

\section{EXPERIMENTAL}

\section{Description of the atomic absorption spectrophotometer}

The arrangement of the principal components (the magnesium lamp, atomizer, spray chamber, burner, monochromator and detection system) is shown in Fig. 1 .

Magnesium lamp. The lamp, generating light of the magnesium resonance frequency, is a quartz-windowed,

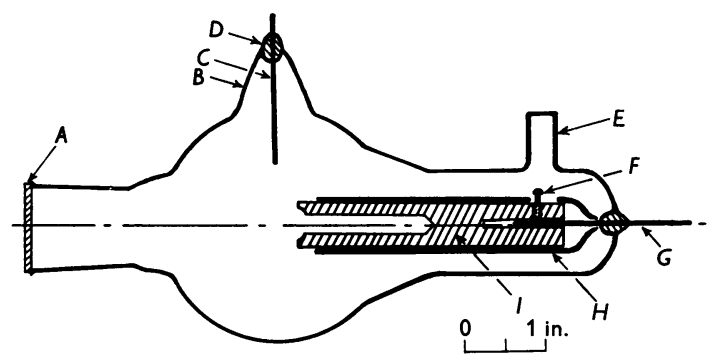

Fig. 2. Magnesium lamp. $A$, Quartz window sealed to glass envelope with black wax; $B$, glass envelope; $C$, tungsten anode; $D, C 79$ glass-to-metal seal; $E$, sealed-off connexion to vacuum system; $F$, screw locking cathode in position; $G$, tungsten-rod support for cathode; $H$, hard-glass sleeve; $I$, hollow magnesium cathode. 


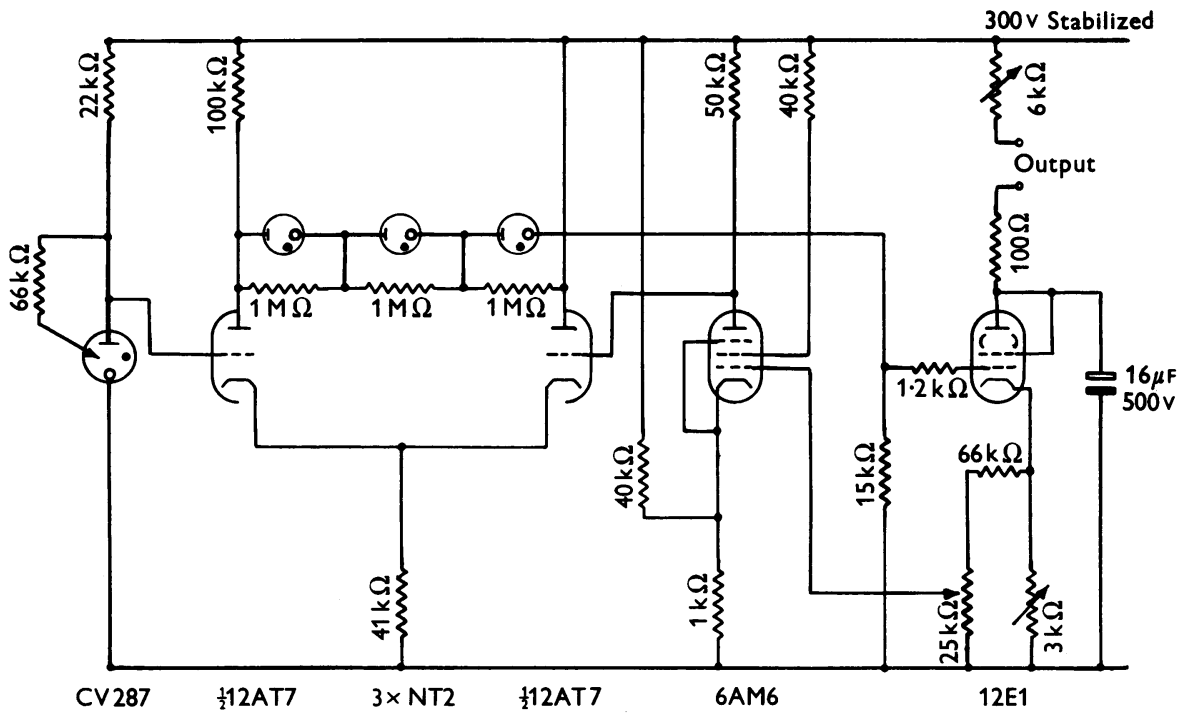

Fig. 3. Circuit diagram of current-regulated power supply for magnesium lamp.
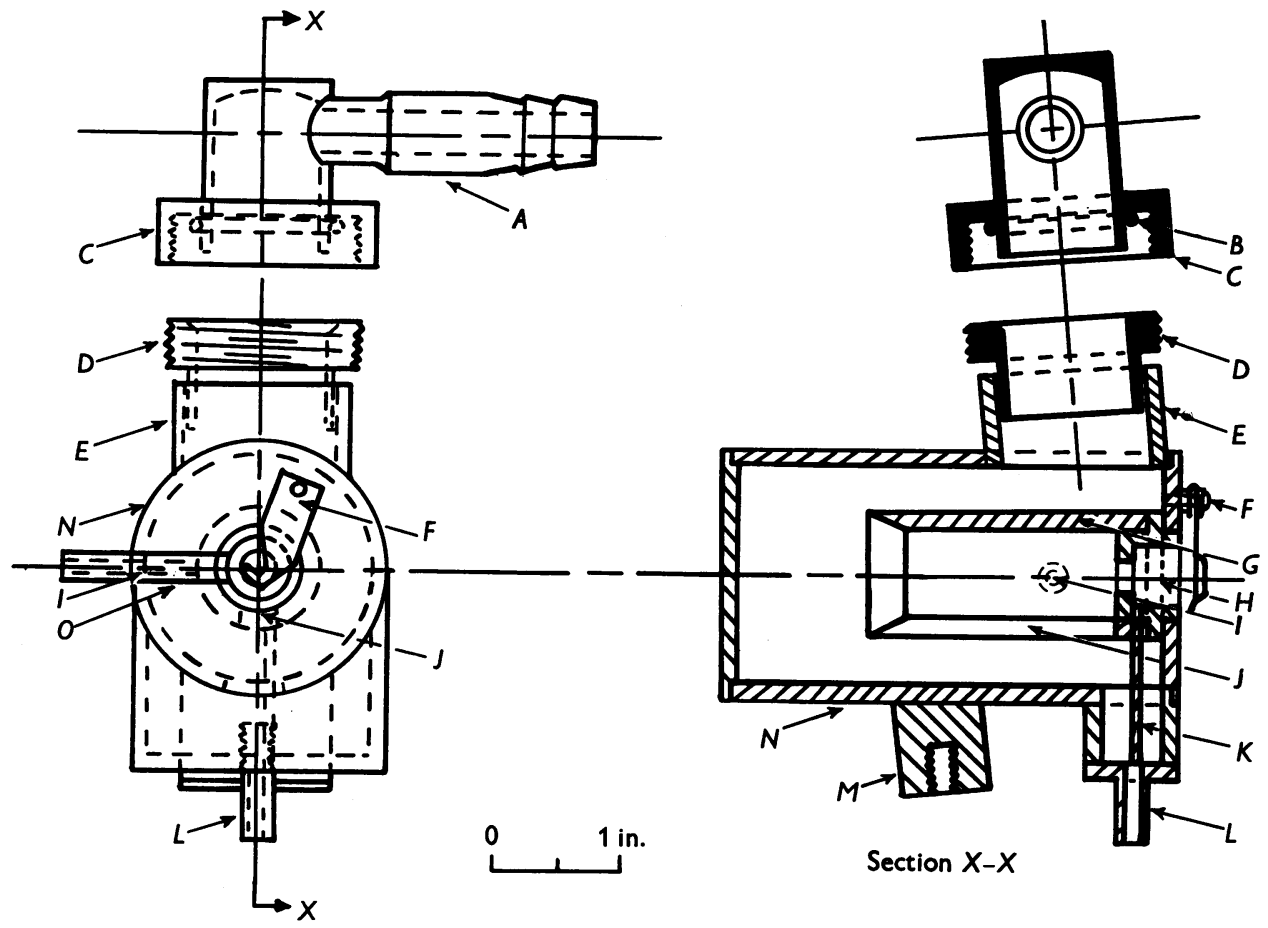

Fig. 4. Spray chamber. $A$, Connexion to burner; $B$, O-ring seal; $C$, knurled locking ring; $D$, threaded brass flange; $E$, Perspex tube at angle of $5^{\circ}$ to main body; $F$, clip to secure EEL atomizer; $G$, inner Perspex cylinder; $H$, recess for atomizer; $I$, acetylene inlet; $J$, slit in inner cylinder for drainage; $K$, rod guiding drops to outlet; $L$, drain; $M$, block fastening chamber to bench; $N$, outer Perspex cylinder; $O$, groove to accommodate side arm of atomizer. 
hollow magnesium-cathode discharge tube, filled with argon at a pressure of $1-2 \mathrm{~mm}$. $\mathrm{Hg}$ (Fig. 2). Power is supplied to the lamp by a current stabilizer (Fig. 3), which is fed from a Solartron constant-voltage supply, type AS 517 (Solartron Electronic Group Ltd., Thames Ditton, Surrey).

Gas supply. Air and acetylene are supplied from cylinders fitted with two stage regulators (types BOR 12 and BAR 9 respectively, British Oxygen Gases Ltd., Wembley), fine control of the acetylene flow rate being provided by a needle valve situated on the instrument.

Atomizer. The atomizer is of the type used in the EEL flame photometer (Evans Electroselenium Ltd., Harlow, Essex).

Spray chamber. This is constructed of Perspex (Fig. 4), the drain running into a sealed bottle to help maintain a steady gas pressure in the chamber.

Burner. The burner, constructed of brass, is watercooled to eliminate instability due to temperature variation (Fig. 5). A diaphragm is inserted in the light-path to restrict absorption measurements to the optimum part of the flame.

Monochromator and detection system. This consists of the monochromator and detection system of the CF 4 spectrophotometer (Optica U.K. Ltd., Gateshead-on-Tyne), the lamp housing being replaced by a parallel-bar optical bench. On the bench are mounted the magnesium lamp, a condenser lens, the burner and a mirror which reflects the light into the entrance slit of the monochromator.

\section{Preparation of the atomic absorption spectrophotometer}

The positions of the lamp, lens and mirror are adjusted to pass maximum light into the monochromator (maximum transmission on the extinction scale). The wavelength control is set at $285 \mathrm{~m} \mu$ and then finely adjusted to obtain maximum transmission at the magnesium resonance line $285.213 \mathrm{~m} \mu$. The slit width is set at $0.2 \mathrm{~mm}$. The position of the burner is adjusted until the gas ports are aligned with the optical axis and $12 \mathrm{~mm}$. below this axis. The instrument is checked to ensure that addition of sodium $(17 \mathrm{mg}$. $100 \mathrm{ml}$.) to a standard magnesium solution $(0.05 \mathrm{mg}$. $100 \mathrm{ml}$.) produces no change in extinction. If interference is observed, the height of the burner is adjusted relative to the optical axis until this effect disappears. The instrument is now correctly assembled, and further adjustment is necessary only after moving any part of the equipment.

The atomizer and gas ports in the burner should be cleaned after approximately 100 estimations, and the drain bottle from the spray chamber must be emptied periodically. No other routine maintenance is required.

\section{Operation of the atomic absorption spectrophotometer}

The magnesium lamp is allowed to stabilize for approximately $1 \mathrm{hr}$. before the instrument is used. Cooling water is then passed through the burner, the pressures of air and acetylene are adjusted to 13 and $5 \mathrm{lb}$./in. ${ }^{2}$ respectively, and, with the needle valve fully open, the gas is ignited. The acetylene flow is reduced by means of the needle valve until the white tips just disappear from the cones of unburnt gas in the flame. Water is aspirated into the flame and the sensitivity control is adjusted to give an extinction approaching zero. No attempt is made to adjust exactly to zero as it is impossible to stabilize completely the lightoutput from the lamp.

Estimations may conveniently be carried out in groups containing up to eight unknown solutions. A standard solution containing $0.050 \mathrm{mg}$. of magnesium in $100 \mathrm{ml}$. of $0 \cdot 1 \mathrm{~N}$-hydrochloric acid is measured immediately before and after each group of unknown solutions. The small effect of lamp instability is minimized by spraying water both before and after each magnesium-containing solution, the mean value of these two readings being subtracted from the extinction of the sample. The extinction of every solution is measured twice and, after correction for the distilled
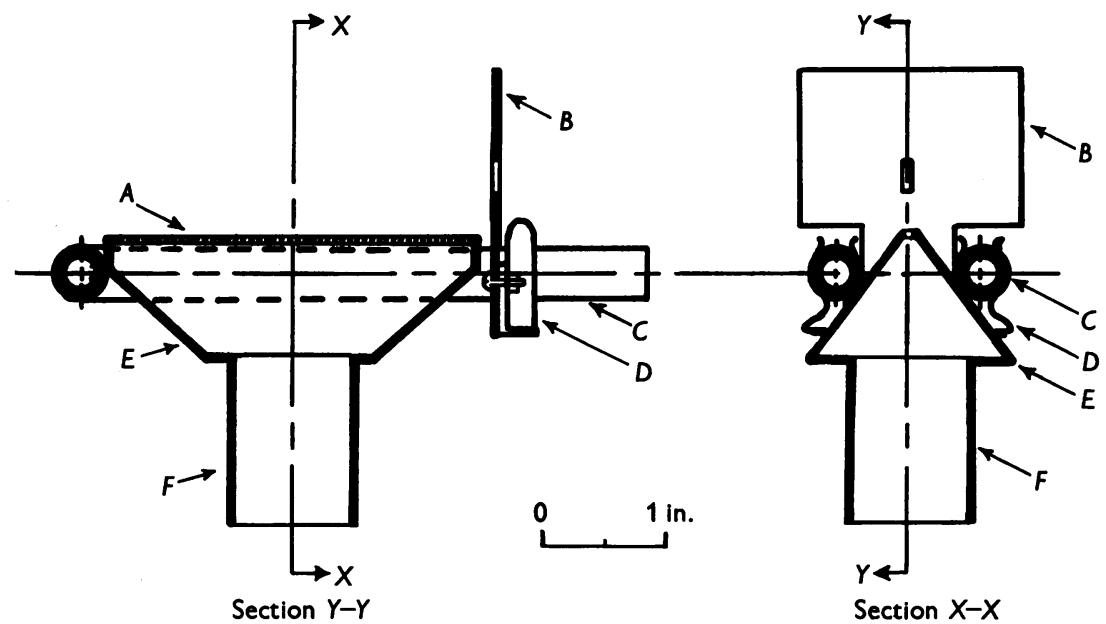

Fig. 5. Burner. $A$, Gas ports (30 $\times 1 \mathrm{~mm}$. diameter); $B$, metal diaphragm; $C$, water-cooling pipes soldered to body of burner; $D$, Terry clips attaching diaphragm to cooling pipes; $E$, burner body fabricated from 16 s.w.G. sheet brass; $F$, connexion to spray chamber. 
water blank, the magnesium content of each unknown is calculated from the ratio of the mean value for its extinction to the corresponding value for the standard solutions.

\section{Preliminary treatment of samples}

Specimens are diluted to produce a solution for measurement in the instrument which contains $0.02-0.08 \mathrm{mg}$. of magnesium/100 ml. Hydrochloric acid (2N) is added to each solution to produce a final concentration of $0 \cdot 1 \mathrm{~N}$.

Plasma or serum. Direct, 50 -fold dilution is satisfactory.

Urine. Dilution 100 times is usually satisfactory.

Blood cells. Packed cells are laked with a considerable excess of water before acidification; 100-fold dilution is satisfactory.

Food and faecal materials. Solid materials are homogenized with water and diluted to a known volume. Suitable portions are transferred to silica crucibles, dried on a sand bath and ashed overnight in a muffle furnace at $500^{\circ}$. The ash is dissolved in $2 \mathrm{~N}$-hydrochloric acid and diluted as described above.

\section{Reagents}

Chemicals. All materials used were of AnalaR quality with the exception of dipotassium hydrogen phosphate and ethylenediaminetetra-acetic acid (disodium salt), which were of laboratory-reagent grade. The standard calcium solution was prepared from dry calcium carbonate dissolved in the minimum quantity of hydrochloric acid. Glass-distilled water was used for the preparation and dilution of all solutions.

Standard magnesium solution. A stock solution of $\mathrm{MgSO}_{4}, 7 \mathrm{H}_{2} \mathrm{O}$ containing $10 \mathrm{mg}$. of magnesium $/ 100 \mathrm{ml}$. is employed. Working strength standards of $0.050 \mathrm{mg}$. of magnesium $/ 100 \mathrm{ml}$. are prepared by dilution, and acidified with hydrochloric acid to $0 \cdot 1 \mathrm{~N}$ in the same manner as the solutions to be analysed. The working standards are stable for 1 week provided they are stored in flasks aged by equilibration with similar solutions.

\section{Chemical estimation of magnesium}

Magnesium was determined by the ammonium phosphate separation method of Simonsen, Westover \& Wertman (1947) for serum magnesium, modified and extended to the analysis of other materials as described by Heaton (1960).

\section{RESULTS AND DISCUSSION}

\section{Development of the method}

Treatment of solutions. Magnesium sulphate and magnesium acetate, the two non-deliquescent magnesium salts readily available in a high state of purity, were examined for use as standards. A neutral aqueous solution of magnesium sulphate produced an absorption appreciably greater than that of an equimolar solution of magnesium acetate (Table 1). When these solutions were treated with acetic acid or sulphuric acid in quantities sufficient to equate their anionic composition, an increased extinction was observed in both cases, and the two solutions gave identical results. Similar agreement was obtained when solutions of both salts were acidified with an excess of hydrochloric acid.

Acidification with hydrochloric acid to a concentration of $0.1 \mathrm{~N}$ was adopted as a routine procedure with both standard and unknown solutions. Under these conditions, a standard solution containing $0.050 \mathrm{mg}$. of magnesium $/ 100 \mathrm{ml}$. produced an extinction of approximately $0 \cdot 10$, and the calibration curve was linear up to a magnesium concentration of $0.10 \mathrm{mg} . / 100 \mathrm{ml}$.

Selection of correct region in the flame. The optimum part of the flame for use in atomic absorption measurements was immediately above the cones of unburnt gas. If the burner was too high relative to the optical axis, addition of other cations to a standard magnesium solution caused an apparent enhancement of the magnesium concentration (Table 2).

\section{Evaluation of the proposed method}

The evaluation of the atomic absorption method reported in this section was carried out with the height of the burner correctly adjusted, and all solutions were acidified with hydrochloric acid as described in the Experimental section.

Interference effects. (a) Inorganic ions. The major inorganic constituents of biological materials were tested for interference at the concentrations at which they normally occur, and at twice these levels. Solutions of suitable salts were added to solutions of known magnesium content, and the apparent magnesium concentration was deter-

'Table 1. Influence of anions on the absorption of standard magnesium solutions

Extinction for $0.050 \mathrm{mg}$. of $\mathrm{Mg} / 100 \mathrm{ml}$.

\begin{tabular}{lcc}
\cline { 2 - 3 } \multicolumn{1}{c}{ Solvent } & $\begin{array}{c}\text { Magnesium } \\
\text { sulphate }\end{array}$ & $\begin{array}{c}\text { Magnesium } \\
\text { acetate }\end{array}$ \\
Distilled water & 0.1108 & 0.1058 \\
Acetic acid, $50 \mu \mathrm{N}$ & 0.1149 & - \\
Sulphuric acid, $50 \mu \mathrm{N}$ & - & 0.1149 \\
Hydrochloric acid, $0.1 \mathrm{~N}$ & 0.1125 & 0.1121
\end{tabular}

Table 2. Effect of burner height on interference produced by other cations

The magnesium concentration was $0.050 \mathrm{mg} . / 100 \mathrm{ml}$.

\begin{tabular}{|c|c|c|c|}
\hline \multirow[b]{2}{*}{$\begin{array}{c}\text { Distance of } \\
\text { burner below } \\
\text { optical axis } \\
\text { (mm.) }\end{array}$} & \multicolumn{3}{|c|}{ Percentage interference } \\
\hline & $\begin{array}{l}\text { Sodium } \\
\text { (17.0 mg./ } \\
100 \mathrm{ml} .)\end{array}$ & $\begin{array}{c}\text { Potassium } \\
\text { (4.0 mg./ } \\
100 \mathrm{ml} .)\end{array}$ & $\begin{array}{c}\text { Calcium } \\
\text { (0.50 mg./ } \\
100 \mathrm{ml} .)\end{array}$ \\
\hline $\begin{array}{r}4 \\
6 \\
8 \\
10 \\
12 \\
14\end{array}$ & $\begin{array}{r}+4.4 \\
-0.2 \\
+0.8 \\
+1.2 \\
0.0 \\
+0.4\end{array}$ & $\begin{array}{l}+3.7 \\
+3.7 \\
+2.2 \\
+2.4 \\
+0.9 \\
+0.8\end{array}$ & $\begin{array}{l}+1.3 \\
+0.7 \\
+1.3 \\
-0.4 \\
+0.1 \\
+1.8\end{array}$ \\
\hline
\end{tabular}


mined, making due allowance for the small blank readings of the added salts. The interference observed with different salts was random in nature (Table 3), varying from +1.0 to $-1.6 \%$ of the magnesium concentration, and was equal to the experimental error of the measurement.

(b) Organic substances. The organic constituents of plasma, blood cells and urine were examined for interference by comparing the magnesium content, measured after simple dilution, with the values obtained after preliminary ashing of the same specimens. Since interference by inorganic ions is negligible the results obtained with ashed material were employed as a standard of reference. Organic material enhanced the apparent magnesium content of all types of specimen (Table 4). With urine and blood cells the enhancement of $0.4 \%$ was insignificant, but with plasma the effect was rather greater $(2 \cdot 3 \%)$.

For the determination of serum magnesium Willis (1960b) advocated dilution with solutions of either the disodium salt of ethylenediaminetetraacetic acid or of strontium chloride to liberate the protein-bound magnesium, which normally constitutes approximately $35 \%$ of the total present in serum (Copeland \& Sunderman, 1952; Prasad, Flink, Zinneman \& McCollister, 1958). Acidification with hydrochloric acid, however, produced results similar to those obtained by these procedures (Table 5), and simple aqueous dilution yielded

Table 3. Interference effects of inorganic ions

The magnesium concentration was $0.0500 \mathrm{mg} . / 100 \mathrm{ml}$.

\begin{tabular}{|c|c|c|c|c|c|}
\hline Cation & $\begin{array}{l}\text { Concn. } \\
\text { (mg./100 ml.) }\end{array}$ & Anion & $\begin{array}{l}\text { Concn. } \\
\text { (mg./100 ml.) }\end{array}$ & $\begin{array}{c}\text { Apparent } \\
\text { Mg concn. } \\
\text { (mg./100 ml.) }\end{array}$ & $\begin{array}{l}\text { Percentage } \\
\text { interference }\end{array}$ \\
\hline $\mathrm{Na}^{+}$ & $\begin{array}{r}8 \cdot 5 \\
17 \cdot 0\end{array}$ & $\mathrm{Cl}^{-}$ & $\begin{array}{l}13 \cdot 1 \\
26 \cdot 2\end{array}$ & $\begin{array}{l}0.0498 \\
0.0499\end{array}$ & $\begin{array}{l}-0.4 \\
-0.2\end{array}$ \\
\hline $\mathbf{K}^{+}$ & $\begin{array}{l}1.96 \\
4 \cdot 01\end{array}$ & $\mathrm{PO}_{4}{ }^{3-}$ & $\begin{array}{l}2 \cdot 39 \\
\mathbf{4} \cdot 88\end{array}$ & $\begin{array}{l}0.0505 \\
0.0502\end{array}$ & $\begin{array}{l}+1 \cdot 0 \\
+0.4\end{array}$ \\
\hline $\mathrm{Ca}^{2+}$ & $\begin{array}{l}0.25 \\
0 \cdot 50\end{array}$ & $\mathrm{Cl}^{-}$ & $\begin{array}{l}0.44 \\
0.88\end{array}$ & $\begin{array}{l}0.0504 \\
0.0499\end{array}$ & $\begin{array}{l}+0.8 \\
-0.2\end{array}$ \\
\hline $\mathrm{NH}_{4}{ }^{+}$ & $\begin{array}{l}0 \cdot 76 \\
1 \cdot 52\end{array}$ & $\mathrm{SO}_{4}{ }^{2-}$ & $\begin{array}{l}2 \cdot 02 \\
4 \cdot 04\end{array}$ & $\begin{array}{l}0.0492 \\
0.0493\end{array}$ & $\begin{array}{l}-1 \cdot 6 \\
-1 \cdot 4\end{array}$ \\
\hline $\mathrm{Fe}^{2+}$ & $\begin{array}{l}1 \cdot 0 \\
2 \cdot 0\end{array}$ & $\mathrm{SO}_{4}{ }^{2-}$ & $\begin{array}{l}1 \cdot 71 \\
3 \cdot 42\end{array}$ & $\begin{array}{l}0.0502 \\
0.0498\end{array}$ & $\begin{array}{l}+0.4 \\
-0.4\end{array}$ \\
\hline $\mathrm{Fe}^{3+}$ & $\begin{array}{l}1 \cdot 0 \\
2 \cdot 0\end{array}$ & $\mathrm{SO}_{4}{ }^{2-}$ & $\begin{array}{l}1 \cdot 71 \\
3 \cdot 42\end{array}$ & $\begin{array}{l}0.0502 \\
0.0502\end{array}$ & $\begin{array}{l}+0.4 \\
+0.4\end{array}$ \\
\hline
\end{tabular}

Table 4. Comparison of magnesium analyses carried out by (a) direct dilution and $(b)$ preliminary ashing of the same specimens

Magnesium concn. (mg./100 ml.)

\begin{tabular}{|c|c|c|c|c|c|}
\hline \multicolumn{2}{|c|}{ Plasma } & \multicolumn{2}{|c|}{ Urine } & \multicolumn{2}{|c|}{ Blood cells } \\
\hline (a) & (b) & (a) & (b) & $(a)$ & (b) \\
\hline $\begin{array}{l}1 \cdot 68 \\
1 \cdot 80 \\
1 \cdot 71 \\
1 \cdot 97 \\
1 \cdot 68 \\
2 \cdot 00\end{array}$ & $\begin{array}{l}\mathbf{1} \cdot 63 \\
1 \cdot 73 \\
\mathbf{1} \cdot 71 \\
\mathbf{1} \cdot 94 \\
\mathbf{1} \cdot 61 \\
\mathbf{2} \cdot 01\end{array}$ & $\begin{array}{l}\mathbf{3} \cdot 11 \\
2 \cdot 79 \\
3 \cdot 40 \\
\mathbf{9 \cdot 8 5} \\
\mathbf{7 \cdot 4 7} \\
\mathbf{5 \cdot 5 1}\end{array}$ & $\begin{array}{l}3 \cdot 18 \\
2 \cdot 86 \\
3 \cdot 40 \\
9 \cdot 70 \\
7 \cdot 47 \\
5 \cdot 41\end{array}$ & $\begin{array}{l}\mathbf{4} \cdot 81 \\
\mathbf{6} \cdot \mathbf{4 6} \\
\mathbf{4} \cdot 48 \\
\mathbf{5} \cdot 67 \\
\mathbf{6} \cdot 07 \\
\mathbf{5 \cdot 5 2}\end{array}$ & $\begin{array}{l}4 \cdot 95 \\
6 \cdot 27 \\
4 \cdot 35 \\
5 \cdot 78 \\
6 \cdot 12 \\
5 \cdot 43\end{array}$ \\
\hline $1 \cdot 81$ & $1 \cdot 77$ & $5 \cdot 36$ & $5 \cdot 34$ & $5 \cdot 50$ & $5 \cdot 48$ \\
\hline
\end{tabular}

Table 5. Effect of various diluents on analysis of plasma

\begin{tabular}{|c|c|c|c|}
\hline \multirow[b]{2}{*}{ Plasma diluent } & \multicolumn{2}{|c|}{ Extinction } & \multirow{2}{*}{$\begin{array}{c}\text { Plasma } \\
\text { Mg concn. } \\
(\mathrm{mg} . / 100 \mathrm{ml} .)\end{array}$} \\
\hline & $\begin{array}{c}\text { Mg standard } \\
(0.050 \mathrm{mg} . / 100 \mathrm{ml} .)\end{array}$ & $\begin{array}{c}\text { Plasma } \\
\text { (diluted } 50 \text { times) }\end{array}$ & \\
\hline Distilled water & $0 \cdot 1161$ & 0.0920 & 1.98 \\
\hline Hydrochloric acid, $0.1 \mathrm{~N}$ & $0 \cdot 1185$ & 0.0910 & 1.92 \\
\hline $\begin{array}{l}\text { Ethylenediaminetetra-acetic acid, } \\
\text { disodium salt, } 10.0 \mathrm{~g} . / \text {. }\end{array}$ & $0 \cdot 1156$ & 0.0900 & 1.94 \\
\hline Strontium chloride, $7.6 \mathrm{~g} . / 1$. & $0 \cdot 1127$ & 0.0872 & 1.93 \\
\hline
\end{tabular}


results $2.5 \%$ higher. It appears therefore that displacement of the protein-bound magnesium either occurs during aqueous dilution or is not necessary for the atomic absorption method, and the substances used by Willis, in relatively large concentrations, may be acting as spectroscopic buffers in a manner similar to hydrochloric acid.

Reproducibility and speed. The average difference between duplicate determinations of the extinction on 40 different solutions was $1.0 \%$. Duplicate estimations of the magnesium content of 20 different specimens varied by an average of $1.5 \%$. This larger error includes both the instrumental error and the volumetric errors involved in the preparation of solutions for assay. After preparation of the solution a single extinction can be measured in approximately $1 \mathrm{~min}$., whereas duplicate measurements of extinctions on a group of ten solutions require $20-30 \mathrm{~min}$.

Table 6. Comparison of the atomic absorption and magnesium ammonium phosphate methods

$\begin{array}{cc}\begin{array}{c}\text { Atomic } \\ \text { Pbsorption }\end{array} & \begin{array}{c}\text { Phosphate } \\ \text { separation }\end{array} \\ 1.87 & 1.78 \\ 1.92 & 1.99 \\ 1.81 & 1.75 \\ 1.64 & 1.68 \\ 1.74 & 1.71 \\ 1.61 & 1.68 \\ 1.89 & 1.81 \\ 1.68 & 1.69 \\ 1.83 & 1.80 \\ 1.66 & 1.59 \\ 2.08 & 2.00 \\ 1.97 & 2.02 \\ 2.24 & 2.09 \\ 1.96 & 1.95 \\ 1.71 & 1.67 \\ 1.80 & 1.73 \\ 1.68 & 1.63 \\ 1.96 & 2.00 \\ 1.84 & 1.81 \\ \text { Mean difference } \\ 0.03 \text { (s.E. } 0.01) \\ \text { Mean }\end{array}$

Food or faecal ash $\mathrm{Mg}$ (mg./100 ml.)

$\begin{array}{cc}\begin{array}{c}\text { Atomic } \\ \text { absorption }\end{array} & \begin{array}{c}\text { Phosphate } \\ \text { separation }\end{array} \\ 6.90 & 7 \cdot 10 \\ 4.81 & 4.80 \\ 5.99 & 6 \cdot 19 \\ 4.54 & 4 \cdot 29 \\ 5 \cdot 41 & 5 \cdot 64 \\ 4.67 & 4.64 \\ \text { Mean } 5.39 & 5.44\end{array}$

Mean difference 0.05 (s.E. 0.07)
Comparison of the atomic absorption and magnesium ammonium phosphate methods. A micromodification of the classical ammonium phosphate method has been used as a routine in this laboratory for the determination of magnesium. The principle of this method is the precipitation of magnesium as the ammonium phosphate salt, the magnesium present in the precipitate being calculated from the phosphate content as determined colorimetrically. Calcium is previously removed by precipitation with ammonium oxalate.

Simultaneous analyses were made on 120 different specimens by the proposed method and the ammonium phosphate separation procedure. Typical results are shown in Table 6. The atomic absorption method produced slightly higher results than the chemical method except with inorganic solutions of food and faecal ash, where the average value for the ammonium phosphate method exceeded that for the atomic absorption procedure by $0.9 \%$. With blood cells, urine and plasma the mean values obtained by the proposed method were respectively $0.8,1.0$ and $1.7 \%$ higher than the corresponding results from the chemical method.

\section{Accuracy of the magnesium ammonium phosphate method}

The systematic errors inherent in this method can be divided into two groups: those which decrease the magnesium content of the final precipitate, and compensatory errors leading to the presence of an enhanced amount of phosphate in the precipitate. The greater sensitivity of the atomic absorption method was used to determine the magnitude of these errors. The magnesium loss was ascertained by determining the total magnesium present in the calcium oxalate precipitate, the supernatant fluid from the magnesium ammonium phosphate precipitate, and the liquid used to wash this precipitate free from excess of phosphate. The magnesium equivalent of the phosphate gain was determined by comparing the magnesium content of the magnesium ammonium phosphate precipitate, as measured directly by atomic absorption spectrophotometry, with the corresponding value obtained by calculation from the phosphate content of this precipitate measured colorimetrically. Suitable blank solutions were measured, and allowance was made for trace contamination introduced by the reagents employed in the chemical procedure. Most of the measurements were carried out on the analyses of serum and urine reported in Table 6.

A total magnesium loss of $2 \cdot 2-2.5 \%$ was observed with both types of material, and this was usually balanced by the phosphate gain, giving results within $\pm 1 \%$ of the true value (Table 7 ). As 
Table 7. Systematic errors in the magnesium ammonium phosphate method

Each value is the mean of 20 estimations.

\begin{tabular}{|c|c|c|c|}
\hline Material & $\underset{(\%)}{\text { Magnesium loss }}$ & $\begin{array}{c}\text { Phosphate gain } \\
(\%)\end{array}$ & $\begin{array}{l}\text { Net error } \\
(\%)\end{array}$ \\
\hline $\begin{array}{l}\text { Serum or plasma } \\
\text { Urine }\end{array}$ & $\begin{array}{l}2.5 \text { (S.E. } 0.5) \\
2.2 \text { (S.E. } 0.4 \text { ) }\end{array}$ & $\begin{array}{l}1.7(\text { s.E. } 0.4) \\
2.3(\text { s.e. } 0.6)\end{array}$ & $\begin{array}{l}-0.8 \\
+0.1\end{array}$ \\
\hline
\end{tabular}

would be expected, however, the phosphate gain was proportional to the magnesium concentration, which is normally greater in urine than in serum. For serum this gain was slightly less than the magnesium loss and so caused underestimation of the magnesium content by $0.8 \%$, but with urine the average phosphate gain exceeded the magnesium loss very slightly, producing results $0.1 \%$ high. As the procedures for the analysis of blood cells and solutions of ashed material are identical with the methods for serum and urine respectively, the errors inherent in the latter analyses may be considered typical of those occurring during analysis of the former materials.

Occasionally larger and non-reproducible errors were encountered, owing to disturbance of the magnesium ammonium phosphate precipitate during manipulation. Estimations where such errors occurred were excluded in the compilation of Tables 6 and 7.

\section{Absolute accuracy of the atomic absorption method}

Direct comparison with the ammonium phosphate procedure showed that the atomic absorption method produces results $0.8,1.0$ and $1.7 \%$ higher than the chemical method with blood cells, urine and plasma respectively, the mean value for ashed material being $0.9 \%$ below that given by the chemical procedure. If allowance is made for the errors in the chemical method, the results obtained by atomic absorption spectrophotometry for plasma, urine and food or faecal ashes differ respectively by $+0.9,+1 \cdot 1$ and $-0.8 \%$ from the correct values. These results are not in exact agreement with the probable errors indicated by interference studies, the discrepancy varying from $0.4 \%$ with blood cells to $1.4 \%$ with plasma. No attempt was made to resolve these differences by studying larger series of analyses, as they are sufficiently small to be without practical significance, and do not affect the conclusion that the atomic absorption method is accurate with all types of material to within $2 \%$ of the absolute value.

\section{SUMMARY}

1. An instrument suitable for the determination of magnesium by atomic absorption spectrophotometry is described.

2. Analyses may be carried out on serum, urine, blood cells and solutions of the ash from food or faecal materials after simple dilution and acidification with hydrochloric acid.

3. No significant effect is produced by other inorganic ions. The organic constituents of samples cause slight overestimation of the magnesium concentration.

4. The magnesium ammonium phosphate method is examined and its accuracy determined.

5. Comparison between analyses carried out by the ammonium phosphate method and the atomic absorption procedure shows the latter to be accurate to within $2 \%$ of the absolute value.

We wish to thank Mr D. J. Ellis, Mr S. Taylor and Mr A. W. Chivers for their invaluable help with the construction and evaluation of the instrument.

\section{REFERENCES}

Allan, J. E. (1958). Analyst, 83, 466.

Briggs, A. P. (1922). J. biol. Chem. 52, 349.

Copeland, B. E. \& Sunderman, F. W. (1952). J. biol. Chem. $197,331$.

David, D. J. (1958). Analyst, 83, 655.

Denis, W. (1922). J. biol. Chem. 52, 411.

Exley, D. \& Sproat, D. (1958). J. sci. Instrum. 35, 202.

Garner, R. J. (1946). Biochem. J. 40, 828.

Gillam, W. S. (1941). Analyt. Chem. 13, 499.

Greenberg, D. M. \& Mackey, M. A. (1932). J. biol. Chem. 96, 419.

Heaton, F. W. (1960). J. clin. Path. 13, 358.

MacIntyre, I. \& Davidsson, D. (1958). Biochem. J. 70, 456.

Orange, M. \& Rhein, H. C. (1951). J. biol. Chem. 189, 379.

Prasad, A. S , Flink, E. B., Zinneman, H. H. \& McCollister, R. (1958). Clin. Res. Proc. 6, 260.

Simonsen, D. G., Westover, L. M. \& Wertman, M. (1947). J. biol. Chem. 169, 39.

Smith, A. J. (1955). Biochem. J. 60, 522.

Vallee, B. L. \& Margoshes, M. (1956). Analyt.Chem. 28, 175.

Walsh, A. (1955). Spectrochim. Acta, 7, 108.

Wilkinson, R. H. (1957). J. clin. Path. 10, 126.

Willis, J. B. (1960a). Spectrochim. Acta, 16, 259.

Willis, J. B. (1960b). Spectrochim. Acta, 16, 273. 